\title{
THE IMPACT OF SPIN-OFF POLICY TO THE PROFITABILITY ON INDONESIAN ISLAMIC BANKING INDUSTRY
}

\begin{abstract}
Abdul Hamid ${ }^{1}$
Abstract. The Impact of Spin-off Policy to The Profitability on Indonesian Islamic Banking Industry. The purpose of this paper is to analyze that the spinoff policy that based on Islamic Banking Act No. 21/2008 had an impact on the profitability ratio of Islamic banking industry in Indonesia. This research used ordinary least square regression. The variable used in this paper is spin-off which is used as a dummy variable, and also included the internal factor of industry such as deposit margin, non-performing financing (NPF), and efficiency ratio (measured by BOPO). The result showed that dummy variable of spin-off, NPF and BOPO had an impact on the profitability in Indonesian Islamic banking industry. The implication of this result is spin-off policy had a good impact on the profitability in Indonesian Islamic banking industry. According to this result, Bank Indonesia should stimulate the Islamic banking unit to spin-off from their parents conventional banks.
\end{abstract}

Keywords: Spin-off, Profitability, Islamic Banking, Regression

\begin{abstract}
Abstrak. Dampak Kebijakan Pemisahan Terhadap Profitabilitas di Industri Perbankan Syariah. Tujuan tulisan ini ialah untuk menganalisis apakah kebijakan pemisahan yang didasarkan pada undang-undang no. 21 tahun 2008 memiliki dampak terhadap tingkat profitabilitas pada industri perbankan syariah di Indonesia. Penelitian ini menggunakan regresi kuadrat sederhana untuk menganalisis dampak kebijakan pemisahan ini. Variabel yang dipergunakan ialah variabel dummy pemisahan, serta dimasukkan beberapa faktor internal seperti marjin deposito, tingkat pembiayaan bermasalah, dan rasio efisiensi (diukur dengan BOPO). Hasil yang didapat menunjukkan bahwa variabel dummy pemisahan, NPF dan BOPO memiliki pengaruh terhadap tingkat profitabilitas pada industri perbankan syariah di Indonesia. Berdasarkan hasil ini, Bank Indonesia sebaiknya menstimulasi unit usaha syariah untuk memisahkan diri dari bank induk konvensionalnya.
\end{abstract}

Kata kunci: Pemisahan, Profitabilitas, Bank Syariah, Regresi

First draft: October, 3rd 2014, Revision: December, 5th 2014, Accepted: December, $20^{\text {th }}$ 2014

Syarif Hidayatullah State Islamic University Jakarta, Jl. Ir. H. Juanda No. 95, Ciputat, South Tangerang, Banten

Email : abdul.hamid@uinjkt.ac.id 


\section{Introduction}

The concept of Islamic banking and finance, which was originally just a theoretical discussion, has now become a reality that grows and develops as a fact. In fact, the current Islamic banking industry has transformed from simply an alternative bank with a bank sharia system that is able to play its role in the world economic arena. Islamic banking and financial institutions continue to experience a significant growth. According to the annual report of the Islamic Development Bank (IDB) in 2009, the Islamic financial institution was expected to grow more than $15 \%$ per year, with a number of Islamic financial institutions is more than 300 spread over 75 countries with an estimated total assets of 500 billion dollars, or around 4,600 trillion rupiah. In other words, the market has now reached only about $10 \%$. From this IDB report, we can conclude that the industry is still promising a remarkable development in the future. Table 1 shows the development of Islamic banking network in Indonesia.

Table 1. Islamic banking network

\begin{tabular}{lccccccccc}
\hline & 2006 & 2007 & 2008 & 2009 & 2010 & 2011 & 2012 & 2013 & 2014 \\
\hline Islamic banking & & & & & & & & & \\
Islamic commercial bank & 3 & 3 & 5 & 6 & 11 & 11 & 11 & 11 & 11 \\
Islamic business unit & 20 & 26 & 27 & 25 & 23 & 23 & 24 & 23 & 23 \\
Islamic rural bank & 105 & 114 & 131 & 138 & 150 & 154 & 158 & 163 & 163 \\
Number of Offices & & & & & & & & & \\
Islamic commercial bank & 349 & 401 & 581 & 711 & 1.215 & 1.349 & 1.745 & 1998 & 2139 \\
Islamic business unit & 183 & 196 & 241 & 287 & 262 & 300 & 517 & 590 & 425 \\
Islamic rural bank & 105 & 185 & 202 & 225 & 286 & 362 & 401 & 402 & 429 \\
\hline
\end{tabular}

Source: Islamic banking statistics, Bank of Indonesia

Islamic banking has grown rapidly in Indonesia. This is shown by the development of third-party funds, financing and distribution of assets in the Islamic banking industry from the years before the regulations regarding the spin-off and after the rule of the spin-off. Seen that from year to year, that an increase in either of assets, third-party funds, and the distribution of financing in Islamic banks.

Table 2. The Growth of Third Party Fund, Financing and Asset (Billion rupiah)

\begin{tabular}{lccccccccc}
\hline & $\mathbf{2 0 0 6}$ & $\mathbf{2 0 0 7}$ & $\mathbf{2 0 0 8}$ & $\mathbf{2 0 0 9}$ & $\mathbf{2 0 1 0}$ & $\mathbf{2 0 1 1}$ & $\mathbf{2 0 1 2}$ & $\mathbf{2 0 1 3}$ & $\mathbf{2 0 1 4}^{*}$ \\
\hline Fundraising & 20.672 & 28.011 & 36.852 & 52.271 & 76.036 & 115.415 & 147.512 & 174.018 & 186.608 \\
Financing & 20.444 & 27.944 & 38.194 & 46.886 & 68.181 & 102.655 & 147.505 & 179.284 & 187.886 \\
Asset & 26.722 & 36.537 & 49.555 & 66.090 & 97.519 & 145.467 & 195.018 & 229.557 & 244.197 \\
\hline
\end{tabular}

Source: Islamic banking statistics, Bank of Indonesia 
On July 16, 2008, has passed Law No. 21 of 2008 concerning Islamic Banking. With the passing of this law provides the legal basis and the national Islamic banking industry is expected to encourage the development of Islamic banking industry for the better. One of the crucial issues in this legislation that can accelerate the development of Islamic banking in Indonesia is related to the separation (spin-off) Islamic business units both voluntary and mandatory if the asset of Islamic banking unit has reached $50 \%$ of the parent bank's assets or after 15 years since the Law No. 21 of 2008 had been applied.

According Tübke (2004) there are several factors that affect the separation process (spin-off). First, the factors associated with the business activity, the first factor is related to the size of the company and the business sector differences between the parent company to its subsidiaries. If the first factor is associated with the Islamic business unit can be positioned as a conventional bank subsidiaries and parent company. Second, the factors associated with the organization and management of the company. Third, factors associated with relationships and support. There are three patterns of relationships that may be created between the parent company with subsidiaries which perform the separation, namely the relationship market (market-Relatedness), the relationship of the product (product Relatedness), and the relationship of technology (technology-Relatedness). Fourth, transfer factor or transfer such transfer of experience from the parent company to its subsidiaries. Fifth, factors associated with motivation. Sixth, the factors associated with the business environment in the form of the characteristics of the regional business environment and legal framework

In the year of 2010 - 2011, many of Islamic banking Unit (UUS) decided the spin-off (separate themselves from the Parent Bank) to establish Islamic Banks (BUS), with a reason to promote Islamic banking and more independent management. From 11 Islamic Banks (BUS), who was born purely through the spin-off Islamic banking unit are BJB Syariah and BNI Syariah, while others have appeared Islamic banks through acquisitions, such as the Bank of Syariah Mandiri derived from the acquisition of Bank of Susila Bakti, Bank Mega Syariah of acquisition of Tugu Bank, and BCA Syariah through Bank of Jasa Artha. Moreover, the spin-off through the acquisition then subsequently converted, such as Bank of Syariah Bukopin. BRI Syariah through Bank of UIB, Victoria Bank through Swaguna Bank, Maybank Syariah through Maybank Indocorp. Separation initially considered beautiful, it was not as easy to do, there were Islamic banks that successful in the spin off, but there were also Islamic banks experience some setbacks in spin-offs when becoming Full-pledge Islamic banks.

Spin-off policies that have been implemented in 2008, are still not able 
to reach the target market share of 5\% of the national banking assets as well as the phenomenon of Islamic Banks spinoff spin-offs are still not strong visible management of indicators financial performance displayed. Accordingly, this study sought to determine the impact of policy separation (spin-off) of Islamic banking Unit (UUS) into Islamic Banks (BUS) to third party funds in the Indonesian Islamic banking industry.

\section{Literature Review}

Until now there has not been a lot of theories or research found associated with the spin-off in Islamic banks. This is due to the spin-off of the new Islamic banks only first practiced in Indonesia. Therefore, theories or models of the spin-off will be done with the model of spin-offs are applied to industry in general.

Nasuha (2012) done the research about the performance difference on Islamic banking unit that decided to spin-off, such as BNI Shariah, BRI Shariah, BJB Shariah, BSB and Victoria Shariah. The research is done by Wilcoxon Match Pairs test that saw the performance between before and after the spin-off decision on Islamic banking units. The variables of Islamic banks performance are asset, financing, third party funds, net earnings, CAR, NPF, FDR, ROA and ROE. The result shown that only asset, financing and third party funds that shown a difference between before and after spin-off policies on that five banks. Otherwise for other variables such as CAR, FDR, ROA and ROE shown that there were no difference on CAR, FDR, ROA and ROE in Islamic banks. This result might be due to the spin-off is new practiced in the Islamic banking industry, so the testing period was short on this research.

Al Arif (2014) conducted a study about the impact of spin-off policy on the growth of Islamic banking industry, which one the growth indicator is asset growth. This research uses the data on Islamic banking statistics from Bank of Indonesia and Financial Service Authority. The result shows that all the independent variables such as spin-off dummy variable, one-month time deposit, operational efficiency ratio (BOPO), and profitability ratio (ROA) had an impact on the asset growth on Islamic banking industry in Indonesia.

According Elfring and Foss (1997) there are two types of spin-off, namely: first, in terms of its parent company, in which the parent company for some reason is not able or not able to exploit the opportunities that come by. The second type is related to organizational units as an individual, in this second type is the type most widely performed, in which the subsidiary is not the same as its parent company. This second type contained in the spin-off of the Islamic banking units in conventional banks in Indonesia. 
Beeson and Hyden (2002) stated that if a lot of company done the spinoff to increase the competitiveness of the company and create the value for the shareholders by focused on it primary business. Christo and Falk (2006) showed that the key factor of spin-off is the focused of the industry. From these result and we related to this research, we can stated that the spin-off decision that had been done by several Islamic banking unit can give a value for the parents company and also for the shareholders. Because the parents company can focused on his primary business, and the subsidiary company can focused to develop.

Chemmanur and Yan (2004) develops a new rationale for corporate spinoffs, and for the performance and value improvements following them. The firm has two divisions, and current management has differing abilities for managing these two divisions. Spin-offs can enhance firm management. In addition, on their analysis demonstrates that in addition to positive abnormal stock-price return on the announcement day, spin-offs also lead to positive long-term abnormal stock returns (on average) for parent spin-offs combination reporting subsequent takeover activity.

\section{Methods}

To achieve the goal of this research analyzing the influence of spin-off policy on the profitability ratio of Indonesian Islamic banking, regression analysis is used. The mathematical equation proposed in this research is:

$$
\begin{aligned}
& \mathrm{Y}_{\mathrm{t}}=\beta_{0}+\beta_{1} \mathrm{D}_{\mathrm{t}}+\beta_{2} \mathrm{X}_{1 \mathrm{t}}+\beta_{3} \mathrm{X}_{2 \mathrm{t}}+\beta_{4} \mathrm{X}_{3 \mathrm{t}}+\varepsilon \\
& \quad \text { where: } \\
& Y_{t}=\text { ROA; } \\
& D_{\mathrm{t}}=\text { Dummy variable for spin-off } \\
& \text { Which is: } 0 \text { before spin-off, } 1 \text { after spin-off; } \\
& X_{1 t}=\text { Non-performing financing (NPF); } \\
& X_{2 t}=\text { One-month deposit margin; } \\
& X_{3 t}=\text { BOPO }
\end{aligned}
$$

After processing the regression analysis, to see whether the model is good or bad, we have to know the goodness of fit of the model. To see the goodness of fit of the model, we have to look at the $t$-statistics, F-statistics, the coefficient of determination $\left(R^{2}\right)$, as well as to cover classical assumption test heteroscedasticity, autocorrelation, and multicollinearity.

Decision to accept or reject Ho was made on the basis of the value of the test statistic obtained from the existing data. Under the normality assumption followed the statistical distribution of variable $t$ with degrees of freedom $N-k$. A statistic is said 
to be statistically significant if the value of the test statistic is in the critical region. The aim of statistical $t$ test is to see how big the effect of independent variables on the dependent variable individually.

Testing the null hypothesis is with $F$-statistics is necessary to test if $\bigotimes_{k}=0$. The calculation of $F$-statistics performed by comparing the critical value $F$ obtained from $F$ distribution table at a certain significance level. If the null hypothesis is rejected, it means that the independent variables affect the dependent variable. In this case, the empirical treatment aims to look at the effect of independent variables on the dependent variable.

The coefficient of determination or $R^{2}$ is a measure of goodness of fit which explained whether the linear regression is in line with observational data. Kennedy (2008) said the coefficient of determination, $R^{2}$, to represent the proportion of the variation in the dependent variable explained by variation in the independent variables. If $R^{2}=1$, it means perfect relationship between independent variable and dependent variable, otherwise $R^{2}=0$ means no relationship between independent variable and dependent variable.

\section{Discussion}

According to data processing based on Islamic banking statistics, we get the equation from this model as follows:

\begin{tabular}{|c|c|c|c|}
\hline SE & $\begin{array}{l}0.0511 \mathrm{BOPO} \\
(0.5575) \quad(0.2434) \\
(0.0082)\end{array}$ & $(0.0424)$ & $(0.0045)$ \\
\hline
\end{tabular}

Where:

$R^{2} \quad=0.81982$;

Adj. $R^{2}=0.80647$;

$F$-statistic $=61.4237$.

From the results obtained above, it is seen that the coefficient of the constant value is 4.56672 , meaning that when all other variables are assumed to be zero; the profitability ratio will still increase every month. Then for the spin-off dummy coefficient, which is zero if the period time before the enforcement of spin-off policy and 1 if the period time after the enforcement of spin-off policy, has a positive sign. It means that there is a positive relationship between the spin-off policy and the increasing of Islamic banking profit. The value of $t$-test shown a significant result implied that there is an effect between spin-off policies based on Law of 21/2008 about Islamic banking to the profit of Islamic banking industry in Indonesia. 
The first control variable is the ratio of NPF in Islamic banks which shown that $\mathrm{t}$-test value is higher than the $\mathrm{t}$-table value; it means that there is a relationship between NPF and profitability ratio that held by Islamic banks. These results indicate that the health of banks into one of the determinants of Islamic banking profits. From these result showed that the increasing of NPF in Islamic banks will decrease the profit in Islamic banks.

The second control variable is margin of one-month time deposit which shown that $\mathrm{t}$-test value is lower than the $\mathrm{t}$-table value; it means that there is no relationship between one-month time deposit margin and profitability ratio on Islamic banks. The third control variable is efficiency ratio that measured by BOPO. The result showed that there was a relationship between the BOPO ratio and profitability ratio on Islamic banks. These results indicate that the higher level of BOPO in Islamic banks, the profit will decrease. The higher level of BOPO means that the Islamic banks more inefficient, because the operational cost was higher rather than the operational income. This result relevant with the fact, that if Islamic banking is less efficient it will make the profit of that Islamic banks will be decrease.

To see how much this model is influenced by the existing variable, we can use the coefficient of determination. The value of $\operatorname{Adj} . R^{2}$ is 0.80647 , explained that the proportion of the variation in the dependent variable explained by variation in the independent variables was 80.65 percent; the rest is explained by other variables outside of the existing models. Next, to see the simultaneous effect of all independent variables to dependent variable used the F-statistics test. Based on the empirical result shown the $F$-test value is 61.4237 , it means that the existing variables have an influence on the profitability ratio contained in Islamic banking.

From this result we can conclude that spin-off policies that applied to Islamic banking industry in Indonesia had a good effect to increase the profit. This result give a some result that different by the research had done by Nasuha (2013). Nasuha done the research about the performance difference on Islamic banking unit that decided to spin-off, such as BNI Shariah, BRI Shariah, BJB Shariah, BSB and Victoria Shariah. The research is done by Wilcoxon Match Pairs test that saw the performance between before and after the spin-off decision on Islamic banking units. The variables of Islamic banks performance are asset, financing, third party funds, net earnings, CAR, NPF, FDR, ROA and ROE. The result shown that only asset, financing and third party funds that shown a difference between before and after spin-off policies on that five banks. Otherwise for other variables such as CAR, FDR, ROA and ROE shown that there were no difference on CAR, FDR, ROA and ROE in Islamic banks. This result might be due to the spin-off is new practiced in the Islamic banking industry, so the testing period was short on this research. 
Beeson and Hyden (2002) stated that if a lot of company done the spinoff to increase the competitiveness of the company and create the value for the shareholders by focused on it primary business. Christo and Falk (2006) showed that the key factor of spin-off is the focused of the industry. From these result and we related to this research, we can stated that the spin-off decision that had been done by several Islamic banking unit can give a value for the parents company and also for the shareholders. Because the parents company can focused on his primary business, and the subsidiary company can focused to develop.

Veld and Veld Merkoulova (2002) doing the research in 156 spin-off in Europe since 1987 until September 2000, the result showed that there is an increasing of abnormal earning is about $3.57 \%$ for company that focused on its core business, and only $0.76 \%$ for company that not focused on its core business. Herzeca (1996) stated that spin-off has been successfully used to facilitate the achievement of our strategic objectives with as allow it to focus on its core business. Herzeca further argued that the spin-off has been able to effectively separate the business capital of the businesses that have high growth. In addition to the spin-off can eliminate the conflicts that exist in two different businesses.

Agarwal et.al (2004) suggested that the separation is often formed to capitalize on the knowledge that is created by their parent company but not exploited. This explains why the company better, may create more knowledge, but it may have a higher level of separation. This model explains the reason for separation as to develop knowledge of the less exploited by its parent company. This model shows how the separation (spin-off) provides a mechanism to compensate for ability limitation of companies to evaluate new ideas.

From the results obtained, then associated with several previous studies showed that the spin-off policy has a good influence on the development of the industry. This is similar to the case of the spin-off policy in the Islamic banking industry in Indonesia, where the spin-off policy proved to increase the growth of third party funds in the Islamic banking industry.

\section{Conclusion}

Spin-off policy as contained in the Law 21 in 2008 is one of the breakthroughs that aims to accelerate the growth of Islamic banking in Indonesia. The model proposed in this study uses regression with a dummy variable, as well as control variables in the form of internal factors such as the NPF, margin, and BOPO. The results showed that the dummy variable of spin-off, NPF and BOPO give a significant influence on the profitability ratio (measured by ROA) of Indonesian Islamic banking industry. But, the deposit margin doesn't have an influence on 
profitability ratio. So, we can conclude that the spin-off policy have a significant influence on profitability ratio on Indonesian Islamic banking industry.

The empirical result obtained on this study indicate that the spin-off policy that pursued by the central bank is right. Although there are still some policies are still needed by the Islamic banking industry to grown up rapidly than the growth of conventional banks. The results of this study also helped to support the studies of spin-offs that show a positive influence on the development of the company.

The model in this study still needs to be improved, because the data used in this study used data Indonesian Islamic banking industry in general. Therefore it is recommended for future research may use data derived from each Islamic banking unit who have decided spin-off into Islamic banks. It is intended that the analysis obtained more sharp and accurate in giving an overview of the effect of the spin-off policy towards the Islamic banking.

\section{Reference}

Al Arif, M.N.R. 2014. The Impact of Spin-off Policy on Islamic Banking Industry in Indonesia. Working Paper, UIN Syarif Hidayatullah Jakarta.

Bchini, B. 2012. Spin-off: Factor of Growth and Entrepreneurial Success: The Example of Tunisia. International Journal of Business and Social Science, Vol. 3, No. 12, June 2012, page 65-75.

Beeson, J. \& C. Hyden. 2002. Corporate Spin-offs: Gaining focus and unleashing stockholder value. Orange County Business Journal, Sept 30 - Oct 6, 2002, 39: pp 14

Castello, P.M.P, et.al. 1999. The Impact of Corporate Spin-offs on Competitiveness and Employment in The European Union. Sevilla: IPTS Technical Report Series, European Comission

Chemmanur, T.J. \& An Yan. 2004. A Theory of Corporate Spin-offs. Journal of Financial Economics, Elsevier, Vol. 72, Issue 2, May 2004, pages 259-290.

Chu, P.Y, et. al. 2010. Spin-off Strategies and Performance: A case study of Taiwan's Acer Group. Asian Business and Management, 2010, Vol. 9, 1, page 101-125

Cristo, D.A. \& R.W. Falk. 2006. Spinoffs and Carveouts: Some Factors Leading to Successful Divestiture. Competition Forum, Vol. 4, 2.

Elfring, T. \& N.J. Foss. 1997. Corporate Renewal Through Internal Venturing and Spin-offs: Perspectives from Organizational Economics. Working Paper 97-7, Department of Industrial Economics and Strategy Copenhagen Business School.

Elpida, et.al. 2010. The Spin-off Chain. Journal of Management and Innovation, 2010, Vol. 5, Issue 3, pp. $51-68$. 
Herzeca, L. 1996. Spin-offs: The Latest Divestitute Fad. Best's Review, Vol. 97, 4 page 65.

Jongbloed, M. 2004. Spin-offs: Implication for Corporate Policies. Vol. XLIX, 4, 2004, page 569-588.

Klepper, S. 2011. Nano-economics, Spinoffs, and The Wealth of Regions. Small Business

Economics, Springer, vol. 37 (2), pp. 141-154.

Klepper, S. \& S. Sleeper. 2005. Entry by Spinoffs. Management Science, Vol. 51, No. 8, August 2005, pp. $1291-1306$.

Klepper, S. \& P. Thompson. 2010. Disaggrements and Intra-Industry Spinoffs. International Journal of Industrial Organization, Elsevier, vol. 28(5), September 2010, pp. 526-538.

Kim, J. 2011. Corporate Restructuring Through Spin-Off Reorganization Plan: A Korean Case Study. Pace International Law Review, Vol. 23, Issue 1, Winter 2011.

Miles, J.A. \& J.D. Rosenfeld. 1983. The Effect of Voluntary Spin-Off Announcement on Shareholder Wealth. The Journal of Finance, Vol. XXXVIII, No. 5, December 1983, pp. 1597 - 1606.

Miles, M.P., et. al. 1992. The Degree of Marketing and Entrepreneurial Orientations in Spinoff and Non-Spinoff Organizations. Journal of Business and Entrepreneurship, Vol. 4, Number 2, July 1992. Page. 67-75

Nasuha, A. 2012. The Impact of Spin-off Policy on Islamic bank's Performance. Jurnal Iqtishad Fakultas Syariah dan Hukum UIN Syarif Hidayatullah Jakarta, Vol. IV, No. 2Juli 2012, pp. 241-258.

Rizqullah. 2013. The Alternative Methods of Islamic Banking Unit into Islamic Commercial Banking. (Dissertation Unpublished). Jakarta: University of Trisakti.

Semadeni, M.B. 2003. Leaving The Corporate Fold: Examining Spin-off Actions and Performance. Dissertation of Graduate Studies of Texas and A \& M University.

Thompson, Peter dan Steven Klepper. 2005. Spinoff Entry in High-tech Industries: Motives and Consequences. Working Papers 0503, Florida International University, Department of Economics.

Veld, Chris \& Yulia V Veld-Merkoulova. 2002. Do Spin-offs Really Create Value? The European Case. Research paper, Department of Finance and Center, Tilburg University, Netherlands. 